\title{
Geologic Influences on the Quality of Groundwater Used for Domestic Supply in the Northern Sierra Nevada Foothills
}

Approximately 2 million California residents depend on groundwater from domestic wells for their drinking-water supply. The State of California, in collaboration with the U.S. Geological Survey, created the Groundwater Ambient Monitoring and Assessment Program Priority Basin Project (GAMA-PBP) to assess the quality of groundwater used for domestic supply throughout the state and determine regional vulnerabilities to drinking-water resources. Many rural households in the northern Sierra Nevada foothills (hereafter referred to as "the foothills") use domestic wells that pump water from fractured-bedrock aquifers. In the foothills, complicated and varied regional bedrock geology can cause substantial variation in groundwater chemistry and quality over relatively short distances. This factsheet presents findings from the GAMA-PBP assessment that highlight influences of geologic factors on groundwater quality in the foothills.

\section{Northern Sierra Nevada Foothills Domestic-Supply Aquifer Assessment}

During 2015-17, the GAMA-PBP assessed groundwater quality at 142 sites (wells or developed springs) used for domestic drinking-water supply in the foothills (Levy and Fram, 2021). The Yuba, Bear, North American, South American, Cosumnes, and Mokelumne River watersheds (fig. 1) were chosen for study because of the high density of rural households that rely on domestic wells for their drinking-water supply (Johnson and Belitz, 2015). The primary study objective was to provide a statistically representative assessment of aquifer systems used for domestic drinking-water supply in the foothills. In this region, domestic wells are typically drilled into fractured-bedrock aquifers with a wide range of lithologies (groups of different rocks with common characteristics) and associated water chemistries. Therefore, a major focus of the study was to understand the complicated and interrelated geologic factors that impact the quality of groundwater resources in the region.

\section{Understanding a Complicated Regional Geology}

Bedrock in the foothills is a diverse patchwork of different rock types that began to form more than 100 million years ago in response to the tectonic collision of the ocean floor with the western margin of what is now continental North America (Kistler and others, 1971). The intense heat and pressure caused by the heavier oceanic crust moving beneath the lighter continental crust caused molten magma to flow into the overlying portions of the continental crust and cool into large masses of igneous rocks called plutons, which collectively form the geologic backbone of the mountain range. The foothills study region occupies the Western Metamorphic Belt of the Sierra Nevada where shallower portions of the ocean crust were scraped onto the western flank of the growing mountain range, metamorphosed (compressed and altered by heat and pressure), and then intruded by plutons to form a complicated and varied geologic terrane (Day and others, 1985; Böhlke and Kistler, 1986). Northwest-southeast trending folds and steeply dipping faults are abundant in the foothills, particularly at lower elevations within the Melones fault zone, which occupies the northwest portion of the study region (fig. 1; Clark, 1960).

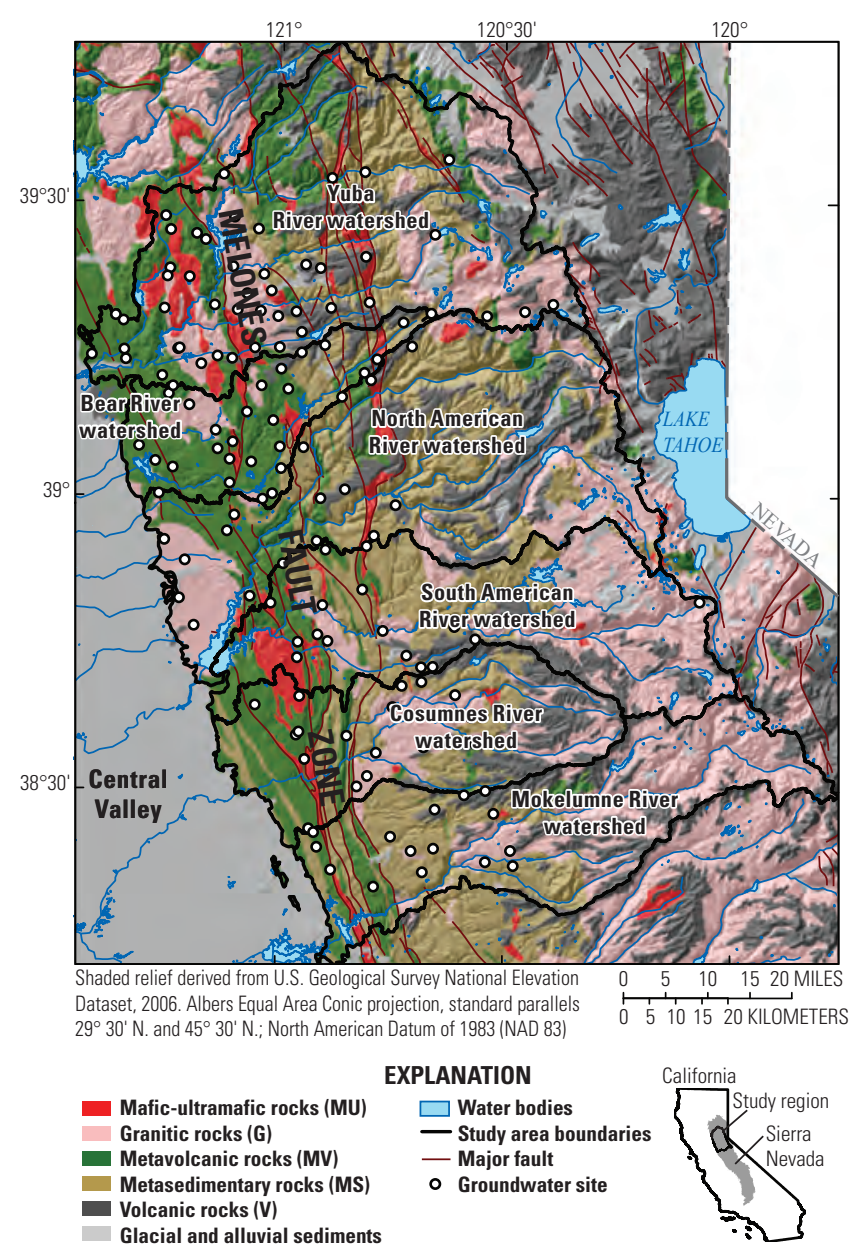

Figure 1. Geologic map of northern Sierra Nevada foothills study region with study watersheds, generalized geology, and groundwater sampling sites (adapted from Saucedo and others, 2000).

In order to simplify the complicated regional geology, California geologic map units within the study region were grouped into five generalized aquifer lithologies (table 1; fig. 1; Levy and Fram, 2021). Plutonic rocks can have varied chemical compositions ranging from light-colored granitic rocks to dark-colored mafic and ultramafic rocks. Granitic rocks are found throughout the study region, whereas mafic and ultramafic plutons more commonly occur as elongate bodies adjacent to major fault zones at lower elevations to the west and northwest. 
Table 1. Features of generalized lithological classes used in foothills groundwater study (Levy and Fram, 2021).

\begin{tabular}{|c|c|c|c|}
\hline $\begin{array}{l}\text { Generalized aquifer } \\
\text { lithology }\end{array}$ & Description & $\begin{array}{l}\text { Examples of common } \\
\text { regional rocks }\end{array}$ & $\begin{array}{c}\text { Percentage of } \\
\text { wells in foothills } \\
\text { groundwater } \\
\text { study }\end{array}$ \\
\hline Mafic-ultramafic (MU) & $\begin{array}{l}\text { Plutonic mafic and ultramafic rocks formed during the } \\
\text { Mesozoic era }\end{array}$ & Gabbro, serpentinite & 8 \\
\hline Granitic (G) & Plutonic granitic rocks formed during the Mesozoic era & Granite, granodiorite & 30 \\
\hline Metavolcanic (MV) & $\begin{array}{l}\text { Metamorphosed volcanic rocks of marine origin formed } \\
\text { during the Paleozoic and Mesozoic eras }\end{array}$ & Greenstone, serpentinite, ophiolites & 34 \\
\hline Metasedimentary (MS) & $\begin{array}{l}\text { Variably metamorphosed marine sediments formed during } \\
\text { the Paleozoic and Mesozoic eras }\end{array}$ & Shale, slate & 16 \\
\hline Volcanic (V) & $\begin{array}{l}\text { Volcanic and volcaniclastic rocks formed during the } \\
\text { Cenozoic era }\end{array}$ & $\begin{array}{l}\text { Assorted lava flows, volcaniclastic } \\
\text { rocks, and mudflow deposits }\end{array}$ & 12 \\
\hline
\end{tabular}

Diverse assemblages of metamorphic rocks derived from oceanic crust and marine sediments were respectively subdivided into metavolcanic and metasedimentary lithologies. The metavolcanic lithology represents metamorphosed volcanic rocks, including sections of ocean crust known as ophiolites, found at lower elevations to the northwest. The metasedimentary lithology represents metamorphosed sedimentary rocks, including slates and shales, found at higher elevations to the southeast.

The volcanic lithology represents broken-up remnants of lava flows called volcaniclastic sediments that cap ridgetops in higher elevation portions of the study area to the east. More recently deposited glacial and alluvial sediments can also be found at higher elevations to the northeast and along the floodplains of major rivers, but domestic wells in the foothills are almost exclusively drilled into the older fractured bedrock, and none of the wells sampled in this study were completed in the younger, overlying surficial sediments. The majority of wells sampled in the foothills groundwater study were located in granitic or metavolcanic aquifers (table 1).

\section{Geologic Influences on Water Quality}

The structure and lithology of fractured-bedrock aquifers can have important impacts on groundwater quality. This is because aquifer rocks and sediments contain minerals that can dissolve in groundwater under various geochemical conditions. The GAMA-PBP assesses groundwater potability by comparing water-quality measurements to established State and Federal standards for public drinking water called benchmarks (Levy and Fram, 2021). Although the quality of groundwater pumped from domestic wells in California is not regulated by State or Federal governments, these benchmark standards provide useful guidelines to evaluate drinking-water quality. Benchmarks can be based on regulatory requirements that are designed to protect human health (health based) or non-regulatory standards for color, taste, or odor (aesthetic). Although hardness (amount of dissolved calcium and magnesium in water) does not have an official State or Federal benchmark, the concentration above which groundwater is considered to be "very hard" (180 milligrams per liter as calcium carbonate; U.S. Geological Survey, 2020) was used as an aesthetic benchmark for the purposes of this study.

Water-quality constituents that have mineral sources in aquifer rocks and sediments were considered geologically derived, as opposed to those that only enter aquifers as a result of human activities at the land surface. Only 5 percent of all wells sampled in the foothills groundwater study exceeded health-based benchmarks for at least one geologically derived trace element or radioactivity indicator (arsenic, barium, boron, molybdenum, strontium, and alpha-particle radioactivity). However, 43 percent of wells in the foothills exceeded aesthetic benchmarks for at least one geologically derived constituent, including iron (12 percent), manganese ( 23 percent), and hardness (27 percent). High levels of iron and manganese can cause a metallic taste, discoloration of water, and formation of metal oxides in pipes that clog plumbing systems. Hard water reduces the efficacy of household soaps and detergents and can form carbonate mineral deposits in pipes that clog plumbing systems. However, geochemical calculations suggest that carbonate mineral deposits are unlikely to form and clog plumbing systems in the study region (Levy and Fram, 2021).

Proportions of wells with groundwater exceeding waterquality benchmarks were calculated for each of the lithological classes (fig. 2). Human-health benchmarks for trace metals and radioactivity indicators were only exceeded in aquifers with mafic-ultramafic, granitic, and metavolcanic lithologies (fig. 2). These three classes also had the hardest groundwater, particularly in mafic-ultramafic and metavolcanic aquifers where the benchmark for hardness was exceeded at over 40 percent of sites. In the foothills, mafic-ultramafic and metavolcanic rocks contain abundant serpentine minerals that can weather to produce alkaline water with high concentrations of trace elements and magnesium, the latter of which directly contributes to water hardness (table 1; Levy and Fram, 2021).

Iron and manganese exceeded aesthetic benchmarks at approximately one third of study sites (fig. 2) and were highest in metasedimentary aquifers. Metasedimentary rocks of marine origin are commonly composed of sediment particles with abundant iron- and manganese-oxide coatings that can dissolve in low-oxygen groundwater (Hem, 1985). The benchmark for manganese was also exceeded at approximately 20 percent of sites with granitic and metavolcanic lithologies, which can also contain iron- and manganese-bearing minerals (Hem, 1985). Concentrated high-manganese deposits are found in ophiolites located in the northwestern portion of the study area that were classified as metavolcanic for the purposes of this study (Flohr and Huebner, 1992). 
Additional geochemical factors can help explain how geology affects water quality in the foothills. The geochemical condition of groundwater is often described using dissolved oxygen and $\mathrm{pH}$, which can control the solubility of different minerals and be used to identify chemical reactions that have already occurred in the water. Iron and manganese are typically mobilized from aquifer materials by low-oxygen groundwater. Additionally, high-pH groundwater can be indicative of water-rock interactions with alkaline minerals, such as serpentine, that can increase water hardness and trace element concentrations.

Groundwater from volcanic aquifers had uniformly high dissolved oxygen concentrations (about 8 milligrams per liter) and low $\mathrm{pH}$ values (about 5.5) typical of rain or snow that has infiltrated aquifers with limited water-rock interaction (fig. 3; Hem, 1985). These volcanic aquifers also tended to have groundwater with lower concentrations of hardness and trace elements than the other lithologies (fig. 2). Overall, wells located in volcaniclastic sediments at high-elevation ridgetops produced groundwater of particularly high quality.

Groundwater from the granitic, metavolcanic, and metasedimentary aquifers tended to have lower dissolved oxygen concentrations and higher concentrations of iron and manganese (figs. 2, 3), indicating iron and manganese are likely mobilized from these aquifers by low-oxygen groundwater. Groundwater from mafic-ultramafic and metavolcanic (and to a lesser degree, granitic) aquifers tended to have higher $\mathrm{pH}$ accompanied by higher levels of trace elements and hardness (figs. 2, 3), indicating weathering of serpentine-bearing rocks, which are prevalent at lower elevations of the study region within the Melones fault zone (fig. 1). Groundwater $\mathrm{pH}$ and hardness may also be greater in the Melones fault zone because more abundant faults and fractures could provide structural conduits for upwelling of groundwater from deep aquifers to comparatively shallow domestic wells. Deeper groundwater in the region tends to have higher $\mathrm{pH}$ and hardness compared to shallow groundwater because deeper groundwater has moved a greater distance, thereby increasing the potential for water-rock interactions that increase $\mathrm{pH}$ and hardness (Levy and Fram, 2021).

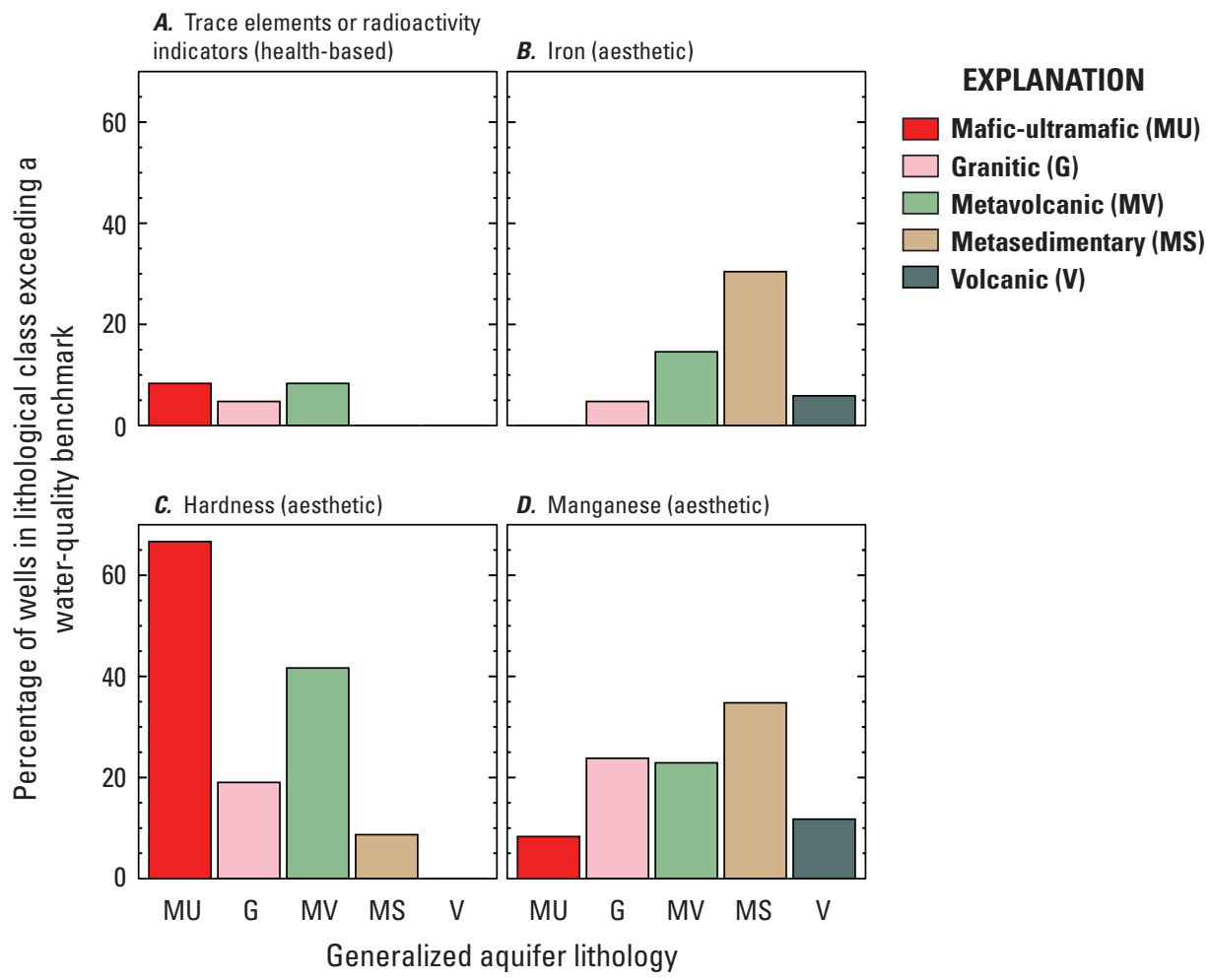

Figure 2. Percentage of wells exceeding health-based or aesthetic water-quality benchmarks for geologically derived constituents as a percentage of wells within generalized lithologic classes.

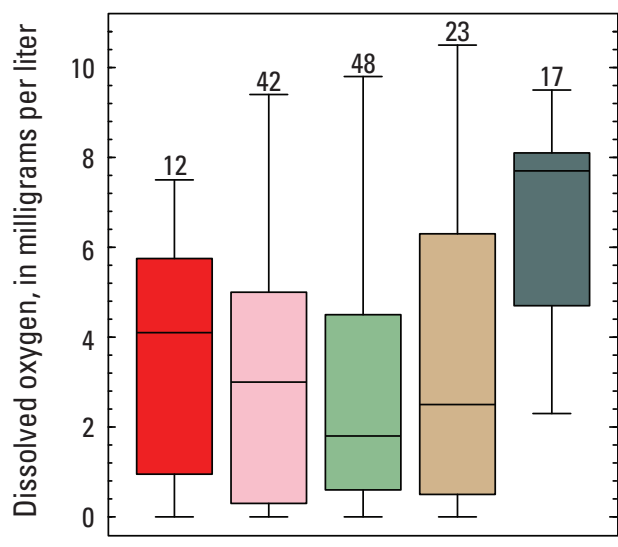

\section{EXPLANATION}

500 Number of values

Largest value within 1.5 times interquartile range above 75th percentile
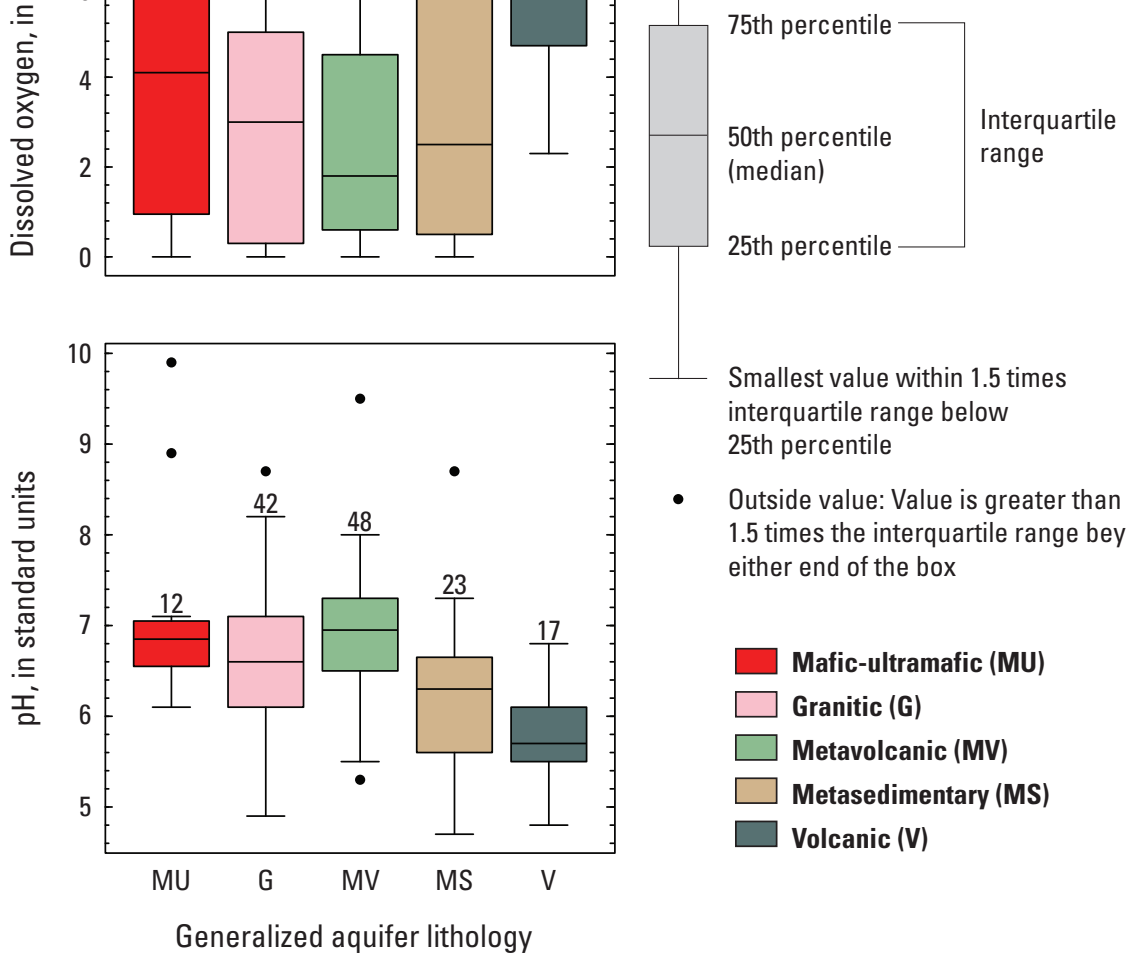

Smallest value within 1.5 times interquartile range below 25th percentile

- Outside value: Value is greater than 1.5 times the interquartile range beyond either end of the box

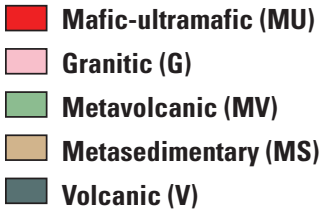

Figure 3. Boxplots depicting relations of generalized aquifer lithology to groundwater dissolved oxygen and $\mathrm{pH}$. 
Overall, very few domestic wells in the foothills had groundwater that exceeded health-based benchmarks. Major water-quality concerns were mostly aesthetic and were related to high concentrations of iron, manganese, and hardness. However, these aesthetic concerns can be costly to mitigate. Therefore, it is important to evaluate the effects of aquifer lithology and geochemical condition on groundwater quality when expanding the use of fractured-rock aquifers in the foothills for domestic drinking-water supply.

By Zeno F. Levy and Miranda S. Fram

\section{References Cited}

Böhlke, J.K., and Kistler, R.W., 1986, Rb-Sr, K-Ar, and stable isotope evidence for the ages and sources of fluid components of gold-bearing quartz veins in the northern Sierra Nevada foothills metamorphic belt, California: Economic Geology, v. 81, no. 2, p. 296-322, http://dx.doi.org/10.2113/gsecongeo.81.2.296.

Clark, L.D.,1960, Foothills fault system, western Sierra Nevada, California: Geological Society of America Bulletin, v. 71, p. 483-496, https://doi.org/10.1130/00167606(1960)71[483:FFSWSN]2.0.CO;2.

Day, H.W., Moores, E.M., and Tuminas, A.C., 1985, Structure and tectonics of the northern Sierra Nevada: Geological Society of America Bulletin, v. 96, no. 4, p. 436-450, http://dx.doi. org/10.1130/0016-7606(1985)96<436:SATOTN>2.0.CO;2.

Flohr, M.J.K, and Huebner, J.S., 1992, Mineralogy and geochemistry of two metamorphosed sedimentary manganese deposits, Sierra Nevada, California, USA: Lithos, v. 29, nos. 1-2, p. 57-85, https://doi.org/10.1016/0024-4937(92)90034-V.

Hem, J.D., 1985, Study and interpretation of the chemical characteristics of natural water (3d ed.): U.S. Geological Survey Water Supply Paper 2254, 263 p., https://doi.org/10.3133/ wsp2254.

Johnson, T.D., and Belitz, K., 2015, Identifying the location and population served by domestic wells in California: Journal of Hydrology_Regional Studies, v. 3, p. 31-86, https://doi. org/10.1016/j.ejrh.2014.09.002.
Kistler, R.W., Evernden, R.W., and Shaw, H.R., 1971, Sierra Nevada plutonic cycle: Part I, origin of composite granitic batholiths: Geological Society of America Bulletin, v. 82 , no. 4, p. 853-868, https://doi.org/10.1130/00167606(1971)82[853:SNPCPI]2.0.CO;2.

Levy, Z.F., and Fram, M.S., 2021, Status and understanding of groundwater quality in the northern Sierra Nevada foothills domestic-supply aquifer study units, 2015-2017: California GAMA Priority Basin Project: U.S. Geological Survey Scientific Investigations Report 2021-5019, 120 p., https://doi. org/10.3133/sir20215019.

Saucedo, G.J., Bedford, D.R., Raines, G.L., Miller, R.J., and Wentworth, C.M., 2000, GIS data for the geologic map of California (version 2.0): California Department of Conservation, Division of Mines and Geology, CD-ROM 2000-007.

U.S. Geological Survey, 2020, Hardness of water: U.S. Geological Survey web page, accessed November 2020 at https://www.usgs.gov/special-topic/water-science-school/ science/hardness-water?qt-science_center_objects $=0 \#$ qtscience_center_objects.

\section{For more information}

Technical reports and hydrologic data collected for the GAMA Program may be obtained from:

GAMA Project Chief

U.S. Geological Survey

California Water Science Center 6000 J Street, Placer Hall

Sacramento, CA 95819

Telephone number: (916) 278-3000

WEB: https://ca.water.usgs.gov/gama

GAMA Program Unit Chief

State Water Resources Control Board Division of Water Quality

PO Box 2231, Sacramento, CA 95812

Telephone number: (916) 341-5855

https://www.waterboards.ca.gov/gama 